\title{
The Effect of Angle Variation in the Model $V$ Blade on the Savonius-Type Vertical Axis Wind Turbine's Performance
}

\author{
Witono Hardi*, Zulkifli S. Tawary, Moh.Muzni Harbelubun, \\ Departemnt of Mechanical Enginerring, Universitas Khairun, Ternate, Indonesia
}

\begin{abstract}
In this study, the researcher applied an experimental method to examine the performance of the Savonius-type turbine, in which variations in the blade angle were $85^{\circ}, 95^{\circ}, 105^{\circ}, 110^{\circ}, 115^{\circ}$, and $125^{\circ}$, variations in wind speed were 3 and $4.1 \mathrm{~m} / \mathrm{s}$, and variations in balancing force were 0.4 and $0.9 \mathrm{~kg}$. The results showed that, of the five examined variations of the blade angle, the $125^{\circ}$ blade produced the highest rotation (n) compared to the others. It generated $115.3 \mathrm{rpm}$ but without a balanced force. Furthermore, the turbine performance at a wind speed $(\mathrm{V})$ of $4.1 \mathrm{~m} / \mathrm{s}$, a balancing force $(\mathrm{F})$ of $0.9 \mathrm{~kg}$, and a blade angle of $125^{\circ}$ produced the rotational speed $(\mathrm{n})$ of $69.6 \mathrm{rpm}$, the turbine power $(\mathrm{Pt})$ of 6.43 watts, the torque $(\mathrm{T})$ of 1.765 N.m, the tip-speed ratio $(\lambda)$ of 0.355 , and the turbine efficiency $66.22 \%$. Meanwhile, at a wind speed of $3 \mathrm{~m} / \mathrm{s}$, a balancing force (F) of $0.9 \mathrm{~kg}$, and a blade angle of $125^{\circ}$, it generated the rotational speed (n) of $28.6 \mathrm{rpm}$, the turbine power $(\mathrm{Pt})$ of 2.64 watts, the torque $(\mathrm{T})$ of $1.765 \mathrm{~N} . \mathrm{m}$, the tip-speed ratio $(\lambda)$ of 0.146 , and the turbine efficiency $69.47 \%$.
\end{abstract}

Keyword: Blade Angle, Savonius-type Turbine, Wind Turbine

\section{Introduction}

In this modern era, renewable energy is highly needed because it is one of the right solutions to overcome the world energy crisis. The fossil energy crisis occurs in almost all parts of the world, including developing countries, such as Indonesia.

Power plants in North Maluku generally use fossil fuels, such as diesel and coal. Meanwhile, fossil energy cannot be renewed, and its availability continues to run low. Furthermore, the natural process to re-produce it takes a long time. Combustion gases in the form of carbon monoxide $(\mathrm{CO})$ and carbon dioxide $(\mathrm{CO} 2)$, which have an impact on global warming are exhaust gases from fossil fuels [1]

Based on Government Regulation No. 76/2014 concerning national energy policy, the use of renewable energy must be a priority, while fossil-based fuel, such as diesel and coal, must be minimized. Therefore, the solution is alternative energy.

For these reasons and considering the potential for wind in North Maluku, especially in Ternate and its surroundings, the government may maximize the Wind Power Plant (Indonesian: Pembangkit Listrik Tenaga Bayu (PLTB)). Although it is in the small to medium scale category, namely below the wind speed of $6.0 \mathrm{~m} / \mathrm{s}$, its wind potential is highly suitable for vertical axis wind turbines, especially the Savonius type, because they can rotate at low wind speeds and wind direction that often changes.
By considering its development to date, blades on the Savonius-type vertical axis wind turbines are generally in the form of a half-cylinder. However, some researchers develop it by varying the number of blades, namely 2, 3, 4, etc. In general, most of them still use the $\mathrm{U}$ and $\mathrm{L}$ blade curves.

Luther Sule (2016), in his study entitled "The Performance of Vertical Axis Windmills with $90^{\circ}$ Curve Blade Model in Various Blade Numbers $(2,3$, and 4 Blades)", found that the $90^{\circ}$ curve blade model with an aspect ratio $(\mathrm{h} / \mathrm{R})$ of 2.8 can achieve a higher power coefficient. In the variation of 2 blades, the gained maximum capability was $28 \%$ at a wind speed of 3.4 $\mathrm{m} / \mathrm{s}$. Besides, in the variation of 3 blades, the accumulated maximum capability was $40 \%$ at a wind speed of $2.2 \mathrm{~m} / \mathrm{s}$. On top of that, in the variation of 4 blades, the gained maximum capability was $25 \%$ at a wind speed of $2.4 \mathrm{~m} / \mathrm{s}$ [2]

The research objectives are to determine the optimum design of the vertical axis wind turbine concerning blade angle.

\section{Literature Review}

Brusca et al. stated that the Reynold Number affected turbine performance. The research on the performance of vertical wind turbines using numerical methods. The Relationship between Reynold Number and the implementation of the turbine was revealed. [3]. The analysis of turbine curvature at an angle of $90^{\circ}$ by

\footnotetext{
* Corresponding author : witono@unkhair.ac.id
} 
Pitriadi Peri et al. Concluded that the best performance of a three-blade vertical axis windmill with a curvature of $90^{\circ}$ has the highest power coefficient value at wind speed $=2.2 \mathrm{~m} / \mathrm{s}$, namely 0.4 . [4].

Rasyid et al. conducted Research on the effect of the number of stages. With the output, namely torque, shaft rotation, and power. It is concluded that the 2-stage vertical axis wind turbine has the highest efficiency on L-shaped blades [5].

The VAWT for household use has been performed previously using the variable arm length under study [6]. The arm's length is modified with gears to produce the most power out of all the variations.

IB. Alit et al. Concluded in their Research that increasing the blade angle of the savonius turbine decreased the turbine performance [7].

Research using CFD (Computational Fluid Dynamic) was carried out by A. Alaimo et al. By examining helix and straight vertical wind turbines in 2dimensional and 3-dimensional modelling. From 3dimensional modelling, it can be seen that the helix type wind turbine has an average torque of $8.75 \%$ compared to the straight type [8].

The VAWT can still rotate at low wind speeds. In another study, Rangga et al. Modified the blade angle of a multilevel savonius type vertical wind turbine with a semi-circular blade. [9].

The portable VAWT design was carried out by Nakhoda et al. [10], namely a small type that can be carried to places with much wind. It is very efficient for small electricity sources like a mobile phone charger.

\section{Methodology}

In this study, the researcher applied an experimental method to examine the performance of the Savoniustype turbine with variations in the angle of the turbine blade. The researcher used the $\mathrm{V}$ model blade, in which variations in the angle were $85^{\circ}, 95^{\circ}, 105^{\circ}, 110^{\circ}, 115^{\circ}$, and $125^{\circ}$. In addition, the researcher also used a fan as a wind source, in which variations in wind speed were 3 and $4.1 \mathrm{~m} / \mathrm{s}$. Furthermore, for the balancing force, the researcher hooked a spring balance to the turbine shaft, in which variations in balancing force were 0.4 and 0.9 $\mathrm{kg}$. Experiment Apparatus can be seen in fig 1 .

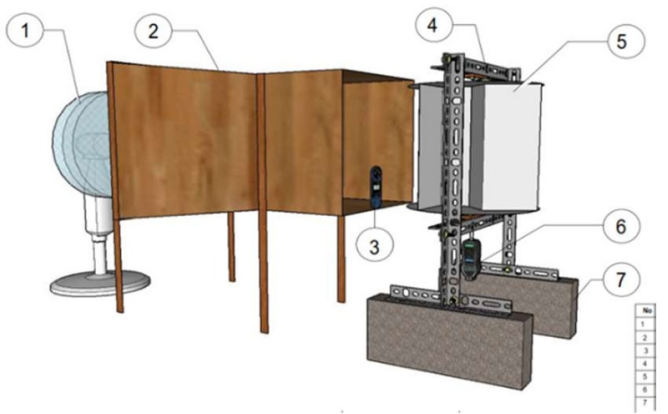

Fig. 1. Experiment Apparatus (1) Fan (2) Wind Tunnel (3) Anemometer (4) Spring Scala (5) Turbine (6) Tachometer (7) Supports

\section{Results And Discussion}

The following calculation example is taken from the data with the condition of the wind turbine given the balancing force.

Wind Power

$$
\begin{aligned}
& P_{a}=\frac{1}{2} \cdot \rho \cdot A \cdot v^{3} \\
& (\rho)=27,9^{\circ} \mathrm{C}=1,17419 \mathrm{~kg} / \mathrm{m}^{3} \\
& \mathrm{~A}=\underline{t_{S} .} \underline{l_{S}} \underline{b_{S}} \\
& \mathrm{~A}=(0,4 \mathrm{~m}) \cdot(0,2 \mathrm{~m}) \cdot(3)=0,24 \mathrm{~m}^{2} \\
& \mathrm{P}_{\mathrm{a}}=\frac{1}{2} \times\left(1,17419 \mathrm{~kg} / \mathrm{m}^{3}\right) \times\left(0,24 \mathrm{~m}^{2}\right) \times(4,1 \\
& \mathrm{m} / \mathrm{s})^{3} \\
& \mathrm{P}_{\mathrm{a}}=9,71 \text { watt }
\end{aligned}
$$

Turbine Torsion

$$
\begin{aligned}
T & =r_{\text {lengan }} \cdot M \cdot g \\
\mathrm{~T} & =(0,2 \mathrm{~m}) \times(0,9 \mathrm{~kg}) \times\left(9,81 \mathrm{~m} / \mathrm{s}^{2}\right) \\
\mathrm{T} & =1,76 \mathrm{Nm}
\end{aligned}
$$

Turbine Power

$$
\begin{gathered}
P_{t}=T . \omega \\
\text { Jika }=\frac{\pi \cdot n}{60} \\
\omega=\frac{3,1 \cdot 469,6}{60}=\frac{218,54}{60}=3,64 \mathrm{rad} / \mathrm{s}
\end{gathered}
$$

Hence, $P_{t}=1,76 \times 3,64$

$$
P_{t}=6,43 \text { watts }
$$

Tip Speed Ratio

$$
\begin{aligned}
& \lambda=\frac{\pi \cdot D \cdot n}{60 \cdot v} \\
& \pi=3,14
\end{aligned}
$$

with turbine diameter $0,4 \mathrm{~m}$ rpm s 69,6 haft rpm and wind velocity $4,1 \mathrm{~m} / \mathrm{s}$ the tip speed ratio:

$$
\begin{aligned}
& \lambda=\frac{3,14 \times{ }_{0,4} \times_{69,6}}{60 \times 4,1}=\frac{87,417}{246} \\
& \lambda=0,355 \mathrm{rad} / \mathrm{s}
\end{aligned}
$$

Turbine efficiency

$$
\begin{aligned}
& \eta_{t}=\frac{P_{t}}{P_{a}} \times 100 \% \\
& \eta_{t}=\frac{6,43 \mathrm{watt}}{9,71 \mathrm{watt}} \times 100 \% \\
& \eta_{t}=66,22 \%
\end{aligned}
$$

From the calculation, it is found that the wind speed (V) is $4.1 \mathrm{~m} / \mathrm{s}$, the temperature is $27.9^{\circ} \mathrm{C}$, the turbine shaft rotation (n) is $69.6 \mathrm{rpm}$, and the balancing force $(\mathrm{F})$ is $0.9 \mathrm{~kg}$. 


\subsection{The Relationship between Turbine Power $\left(P_{t}\right)$ and Balancing Force $(F)$.}

The loading or balancing force provides mechanical resistance (frictional force) on the turbine shaft, resulting in a decrease in the rotation of the turbine shaft and automatically affecting the output power generated by the turbine.

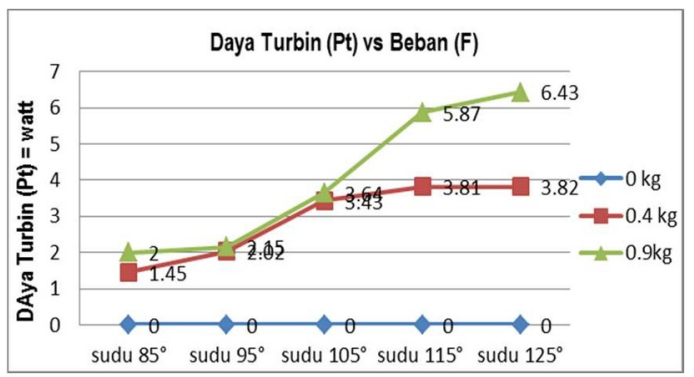

Fig.2. The Relationship between Turbine Power $\left(\mathrm{P}_{t}\right)$ and Balancing Force (F) at a Wind Speed of $4.1 \mathrm{~m} / \mathrm{s}$

As seen in Figure 2, the output power produced by a turbine with a blade angle of $125^{\circ}$ is higher in the balancing force of $0.9 \mathrm{~kg}$ than others, namely 6.43 watts. The same also happens to the $115^{\circ}, 105^{\circ}, 95^{\circ}$, and $85^{\circ}$ blades. In other words, the greater the balancing force given is, the higher the produced turbine output power will be.

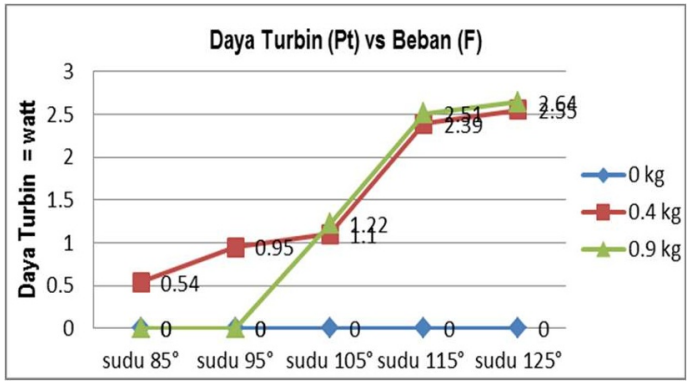

Fig.3.The Relationship between Turbine Power $\left(\mathrm{P}_{\mathrm{t}}\right)$ and Balancing Force (F) at a Wind Speed of $3 \mathrm{~m} / \mathrm{s}$

In the figure above, the output power produced by the turbine at a wind speed of $3 \mathrm{~m} / \mathrm{s}$ with a balancing force of $0.9 \mathrm{~kg}$ is more significant than that with a balancing force of $0.4 \mathrm{~kg}$, namely 2.64 watts. It also happens to all variations of the blade angle. Therefore, the greater the balancing force given is, the higher the produced turbine output power will be.

\subsection{The Relationship between the Tip-Speed Ratio $(\lambda)$ and Balancing Force $(F)$}

The tip-speed ratio (TSR) has the same trend as the RPM because it represents the ratio of the output speed (rotor) to the input speed (wind).

Figure 4 shows that the tip-speed ratio $(\lambda)$ of the $125^{\circ}$ blade turbine is higher than that of other turbines with different blade curves. It is followed by the $115^{\circ}, 105^{\circ}$, $95^{\circ}$, and $85^{\circ}$ blade turbines consecutively.

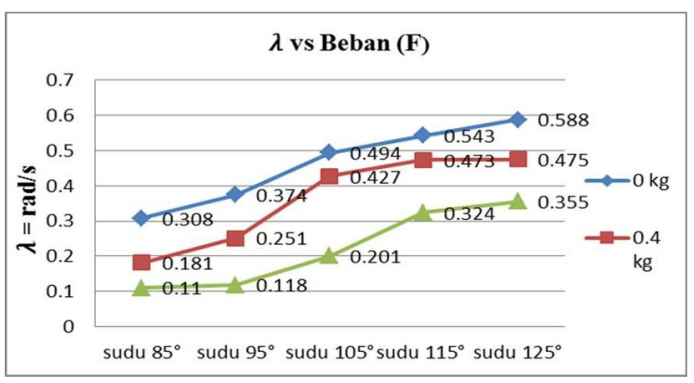

Fig.4. The Relationship between Tip-Speed Ratio $(\lambda)$ and Balancing Force (F) at a Wind Speed of $4.1 \mathrm{~m} / \mathrm{s}$

Meanwhile, Figure 5 indicates that the tip-speed ratio $(\lambda)$ at a wind speed of $3 \mathrm{~m} / \mathrm{s}$ tends to change according to the rotational speed of the shaft produced by the turbine. This happens at all blade angles, in which the lowest number of rotations is gained at the blade angle of $85^{\circ}$. At the blade angle of $95^{\circ}$, it has increased and continues to grow at the blade angle of $105^{\circ}, 115^{\circ}$, and so on. It happens until reaching the blade angle of $125^{\circ}$, recording the highest tip-speed ratio for this blade angle.

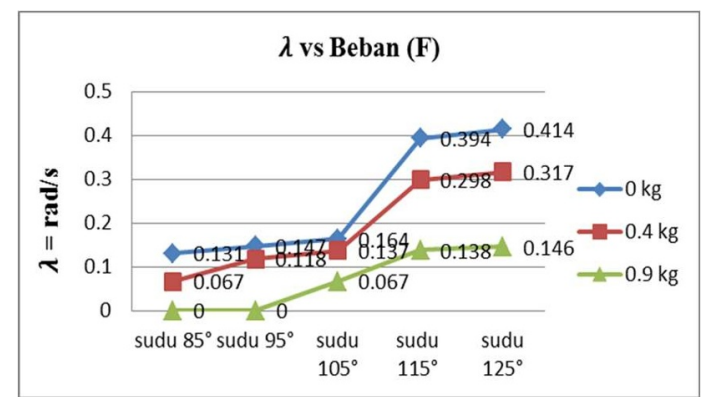

Fig.5.The Relationship between Tip-Speed Ratio $(\lambda)$ and Balancing Force (F) at a Wind Speed of $3 \mathrm{~m} / \mathrm{s}$

\subsection{The Relationship between the Turbine Efficiency $\left({ }^{\eta_{t}}\right)$ and Balancing Force (F)}

As seen in Figure 6, the highest efficiency $\left({ }^{\eta_{t}}\right)$ of the Savonius-type wind turbine is found at the blade angle of $125^{\circ}$, namely $48.06 \%$, at the balancing force of 0.9 $\mathrm{kg}$. However, based on overall observation, the turbine's efficiency will be better if the power generated by the turbine is greater.

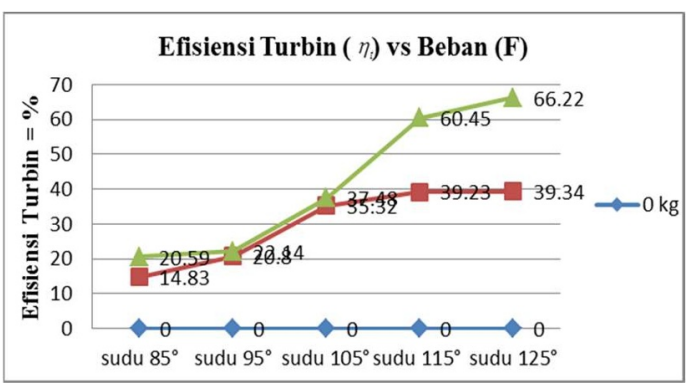

Fig.6.Relationship between Turbine Efficiency $\left(\eta_{t}\right)$ and Balancing Force (F) at a Wind Speed of $4.1 \mathrm{~m} / \mathrm{s}$ 
Furthermore, Figure 7 shows that the smaller the blade angle is, the smaller the gained turbine efficiency $\left(\eta_{t}\right)$. Likewise, the smaller the balancing force given is, the smaller the gained turbine efficiency $\left(\eta_{t}\right)$.

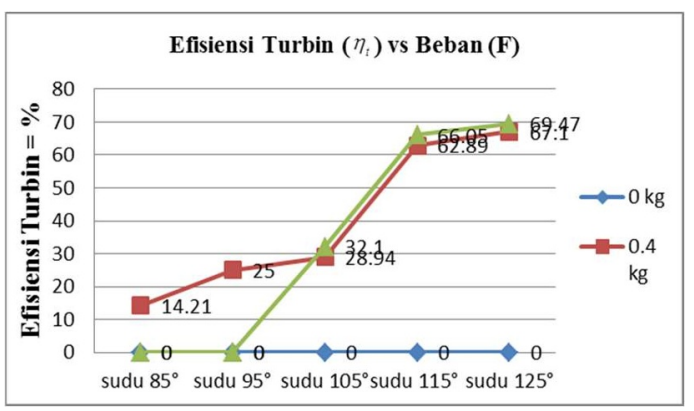

Fig.7. Relationship between Turbine Efficiency $\left(\eta_{t}\right)$ and Balancing Force (F) at a Wind Speed of $3 \mathrm{~m} / \mathrm{s}$

\section{Conclusion}

After all stages in this study are carried out, examining all prototypes of Savonius-type vertical axis wind turbines with the model $\mathrm{V}$ blade in various blade angles, balancing forces, and wind speeds, it can be concluded as follows.

1. Of the five examined variations of the blade angle, the $125^{\circ}$ blade generated the highest rotation (n) compared to the others at a wind speed of $4.1 \mathrm{~m} / \mathrm{s}$, namely $115.3 \mathrm{rpm}$ without given the balancing force, $93.2 \mathrm{rpm}$ with the balancing force of $0.4 \mathrm{~kg}$, and 69.6 $\mathrm{rpm}$ with the balancing force of $0.9 \mathrm{~kg}$. Furthermore, at a wind speed of $3 \mathrm{~m} / \mathrm{s}$, the rotation (n) produced by the $125^{\circ}$ blade was $81.2 \mathrm{rpm}$ without the balancing force, $62.2 \mathrm{rpm}$ with the balancing force of $0.4 \mathrm{~kg}$, and $28.6 \mathrm{rpm}$ with the balancing force of $0.9 \mathrm{~kg}$.

2. The calculation results from the obtained data indicated that the variation of the blade angle that generated the optimum results was the $125^{\circ}$ blade producing $115.3 \mathrm{rpm}$ but without the balanced force. Furthermore, the turbine performance at a wind speed $(\mathrm{V})$ of $4.1 \mathrm{~m} / \mathrm{s}$, a balancing force $(\mathrm{F})$ of 0.9 $\mathrm{kg}$, and a blade angle of $125^{\circ}$ produced the rotational speed $(\mathrm{n})$ of $69.6 \mathrm{rpm}$, the turbine power $\left(\mathrm{P}_{\mathrm{t}}\right)$ of 6.43 watts, the torque $(\mathrm{T})$ of 1.765 N.m, the tip-speed ratio $(\lambda)$ of 0.355 , and the turbine efficiency $\left(\eta_{t}\right)$ of $66.22 \%$. Meanwhile, at a wind speed of $3 \mathrm{~m} / \mathrm{s}$, a balancing force (F) of 0.9 $\mathrm{kg}$, and a blade angle of $125^{\circ}$, it generated the rotational speed (n) of $28.6 \mathrm{rpm}$, the turbine power $\left(\mathrm{P}_{\mathrm{t}}\right)$ of 2.64 watts, the torque $(\mathrm{T})$ of $1.765 \mathrm{~N} . \mathrm{m}$, the tip-speed ratio $(\lambda)$ of 0.146 , and the turbine efficiency $\left(\eta_{t}\right)$ of $69.47 \%$.

\section{References}

[1] Krisna Slamet Rasyid, Sudarno, Wawan Trisnadi Putra. (2012) "Pengaruh Variasi Jumlah Stage Terhadap Kinerja Turbin Angin Sumbu Vertikal Savonius Tipe L". Universitas Muhammadiyah Ponorogo,

[2] Sule, Luther (2016). "Kinerja Kincir Angin Sumbu Vertikal Dengan Model Sudu Bengkok 90 Derajat". Makassar : Universitas Hassanudin,.

[3] S. Brusca, R. Lanzafame, and M. Messina, "Design of a vertical-axis wind turbine: how the aspect ratio affects the turbine's performance," Int. J. Energy Environ. Eng., vol. 5, no. 4, pp. 333-340, 2014.

[4] P. Pitriadi, R. Bachmid, and I. M. Susanto, "ANALISIS PERFORMANCE KINCIR ANGIN SUMBU VERTIKAL TIGA SUDUT DENGAN KELENGKUNGAN 90," J. PoliTeknologi, (2018).

[5] K. S. Rasyid, S. Sudarno, and W. T. Putra, "PENGARUH VARIASI JUMLAH STAGE TERHADAP KINERJA TURBIN ANGIN SUMBU VERTIKAL SAVONIUS TIPE- L," KOMPUTEK, (2018).

[6] A. Putranto, A. Prasetyo, and A. Zatmiko, Rancang Bangun Turbin Angin Vertikal Untuk Penerangan Rumah Tangga. (2011).

[7] I. B. Alit, N. Nurchayati, and S. H. Pamuji, "Turbin angin poros vertikal tipe Savonius bertingkat dengan variasi posisi sudut," Din. Tek. Mesin, vol. 6, no. 2, pp. 107-112, (2016).

[8] A. Alaimo, A. Esposito, A. Messineo, C. Orlando, and D. Tumino, "3D CFD analysis of a vertical axis wind turbine," Energies, vol. 8, no. 4, pp. 3013-3033, (2015).

[9] R. Pangestu and P. N. Bandung, "Turbin Angin Vertikal Savonius Bertingkat Membentuk Helix SAVONIUS BERTINGKAT DENGAN VARIASI BLADE ' SAVONIUS HELICAL L ROTOR' Laporan ini disusun untuk memenuhi salah satu tugas Operasi Sistem Energi II Program Studi Diploma III Teknik Konversi Energi D," no. June, (2017).

[10] Y. I. Nakhoda and C. Saleh, "Rancang Bangun Kincir Angin Pembangkit Tenaga Listrik Sumbu Vertikal Savonius Portabel Menggunakan Generator Magnet Permanen," J. Inov., (2015). 